\title{
Boarding Elementary District Schools Teachers' Views about Elementary School Curricula: Sample of Çankıri*
}

\author{
Elçin ÖZTÜRK ${ }^{* *}$
}

\author{
Fatma BIKMAZ ${ }^{* * *}$
}

\begin{abstract}
The main purpose of this study was to determine Boarding Elementary District Schools (BEDS) classroom teachers' views regarding the 2005 curricula. This study used the qualitative research method to reveal BEDS teachers' views about elementary school curricula in their specific context. Purposeful sampling methods were employed in selecting the subject population for this study. Fifteen classroom teachers volunteered and came from seven BEDS. Data were gathered from the semi-structured interviews during the 2009-2010 school year. The content analysis method was employed to analyze the data. According to the research results most of the BEDS' teachers pointed out that they adopted the 2005 curricula. The majority of teachers stated that the number of students in their classroom, the number of teachers and management staff in their schools were adequate. However some teachers indicated that the BEDS' students have difficulties accessing educational resources. The problems that BEDS' teachers encountered regarding curricula were insufficient principal support, parents' lack of knowledge about curricula and their lack of involvement into school life. For these problems, teachers recommended that principals, teachers and parents should be informed about curricula by university professors or specialists, and the infrastructure of schools need to be improved. In addition, new policies should be developed in order to increase parental involvement.
\end{abstract}

Keywords: Elementary school curriculum, classroom teachers, boarding elementary district school.

\footnotetext{
* This article was summarized from some parts of Master of Arts Thesis which was done in Ankara University Institute of Educational Sciences Department of Curriculum.

** Vice Principal, Ankara-Çankaya Süha Alemdaroğlu Eğitim Uygulama Okulu ve İş Eğitim Merkezi, Ankara, Turkey. E-mail: ozturkelcin80@gmail.com

*** Assoc. Prof. Dr., Ankara University Faculty of Educational Sciences Department of Curriculum, Ankara, Turkey. E-mail: bikmaz@ankara.edu.tr
} 


\section{SUMMARY}

Purpose and Significance: The main purpose of this study was to determine Boarding Elementary District Schools (BEDS) classroom teachers' views regarding the 2005 curricula. BEDS were established for the purpose of providing elementary school services to students, who live in dispersed settlements and less populated areas with adverse climates and limited transportation facilities, and improving their opportunities to complete their compulsory schooling. BEDS have more complicated and different working conditions compared with other public schools. The significance of the study lies herein; it seeks to address to what extent elementary school curricula have been delivered in BEDS and provides substantial data for the curriculum development studies done by Ministry of Education (ME).

Method: This study used the qualitative research method to determine BEDS teachers' views about 2005 curricula in their specific context. Purposeful sampling methods were employed in selecting the subject population for this study. Fifteen classroom teachers volunteered and came from seven BEDS. Data were gathered from the semi-structured interviews during the 2009-2010 school year and each interview session lasted approximately 40 minutes. The source of data for this study included transcripts of interviews with participants. The content analysis method was employed to analyze the data.

Results: According to the research results, most of the BEDS' classroom teachers adopted the 2005 curricula. The majority of the teachers stated that the number of students in their classroom, the number of teachers and management staff in their schools were adequate. However some teachers indicated that the BEDS' students have difficulties accessing educational resources. The majority of BEDS' teachers reported that social conditions of their school supported delivery of the curriculum. However three teachers indicated that due to the lack of information about curricula there were communication problems among teachers and administrators in their school. The majority of BEDS' teachers perceived that their schools' affective conditions were appropriate for the delivering curricula; some teachers felt excluded. Moreover majority of teachers indicated that in order to deliver the curriculum effectively, they needed but did not receive sufficient academic support from other teachers and principals in their schools.

The problems that BEDS' teachers encountered regarding curricula were insufficient principal support, parents' lack of knowledge about curricula and their lack of involvement into school life. For these problems, 
teachers recommended that principals, teachers and parents should be informed about curricula by university professors or specialists, and the infrastructure of schools need to be improved. In addition, new policies should be developed in order to increase parental involvement.

Discussion and Conclusions: Almost all BEDS' teachers indicated that they adopted the 2005 curricula giving the following reasons; students' are actively engage in the learning process, learning is easier, the learning process is more enjoyable, teachers' guide books are more functional and it is integrated with technology. There were a few teachers who indicated that they did not fully adopted and used blended approach for delivering the curricula. In terms of content of the curricula, these teachers also indicated that the earlier curriculum was more efficient and the method for reading and writing was more appropriate. They also indicated that centrally developed curricula were far from meeting the local school needs. These reasons are not specific for BEDS. There are studies that report teachers from other public schools also perceived the 2005 curricula's reading, and writing method was inappropriate (Çelenk, 2002; Korkmaz, 2006; Baydık \& Kudret, 2012), and far from meeting local school needs (Yapıc1 \& Demirdelen, 2007; Y1lmaz, 2008; Uygun \& Genç, 2008).

Teachers, who did not fully adopt the 2005 curricula, reported some problems with regard to curriculum delivery that are specific for BEDS. Problems, such as boarder students having no chance to see their parents frequently and their parents having no chance to be involved in the school life, have effected the success of curriculum delivery directly at BEDS.

A few teachers emphasized that especially boarding students faced with some difficulties in terms of limited access to the educational resources like computers and other educational materials. Majority of teachers indicated that in order to deliver curriculum properly their principals' academic support was not adequate enough. This finding was consistent with the researches done with other public school teachers (Can, 2005; Atmaca, 2007).

Some teachers indicated that they did not delivering curricula efficiently and productively due to the insufficient physical infrastructure of their schools and the inadequate conditions of the school neighborhood. Moreover teachers reported that they did not receive academic support about the curricula. They suggested that collaboration among teachers, principals, students, and parents must be strengthened in order to improve curriculum delivery. They also suggested that the number of activities and assessment tools and forms covered in curricula must be lessened, and the method of reading and writing need to be changed. 
In the light of the results, it can be said that BEDS' teachers adopted the 2005 curricula and most of the problems they encountered seemed not only specific for BEDS but also applicable for other public schools. But some problems such as the boarder students' having lack of parental support and having limited access to educational material, and students' low readiness level for the curricula could be considered more specific for the BEDS' context. To create opportunities for enhancing parental involvement, education programs and projects to improve communication between school and families should be developed. Also to increase students' readiness level, and accessibility to preschool education facilities need to be increased. 


\title{
Yatılı İlköğretim Bölge Okullarında Görev Yapan Sınıf Öğretmenlerine göre İlköğretim Programları: Çankırı İli Örneği
}

\author{
Elçin ÖZTÜRK Fatma BIKMAZ $^{* * *}$
}

ÖZ. Bu araştırma yatılı ilköğretim bölge okullarında (YIBOO) görev yapan sınıf öğretmenlerinin ilköğretim programlarına ilişkin görüşlerini belirlemek amacıyla yapılmıştır. Çalışmada nitel araştırma modeli kullanılmıştır. Amaçlı örnekleme yönteminin kullanıldığ 1 bu araştırmada çalışma grubunu, 2009-2010 öğretim yılında Çankırı ilinde bulunan yedi YİBO'da görev yapan onbeş sınıf öğretmeni oluşturmuştur. Araştırma verileri, yarı yapılandırılmış görüşmelerle toplanmış ve elde edilen verilerin analizinde içerik analizi kullanılmıştır. Araştırma sonuçlarına göre, öğretmenlerin çoğunluğu 2005 ilköğretim programını benimsediklerini ve okullarındaki öğrenci sayılarının ideal olduğunu, öğretmen ve yönetici sayıları açısından bir sorun yaşamadıklarını belirtmişlerdir. Ancak yatılı öğrencilerin materyal, araç gereç temini konusunda sıkıntı yaşadıklarını ifade etmişlerdir. Öğretmenlerin çoğunluğu programın uygulanması sürecinde yönetici desteğine ihtiyaç duyduklarını ancak bu konuda sağlanan desteği yetersiz bulduklarını belirtmişlerdir. YİBO öğretmenlerinin programla ilgili karşılaştıkları sorunlar olarak, yetersiz yönetici desteği, velilerin programı tanımamaları ve okul yaşamına katılımlarının yetersizliği vurgulanmıştır. Öğretmenler uygulamada yaşanan sorunların çözümü için, yönetici, öğretmen ve velilerin öğretim programları hakkında bilgilendirilmesi, okulların eğitim ortamlarının geliştirilmesi, hizmet içi eğitimlerin akademisyenler veya uzmanlar tarafından verilmesi yönünde önerilerde bulunmuşlardır. Ayrıca veli katılımını arttıracak yeni politikaların geliştirilmesi önerilmiştir.

Anahtar Sözcükler: İlköğretim programı, sınıf öğretmeni, yatılı ilköğretim bölge okulu.

\footnotetext{
* Bu makale Ankara Üniversitesi Eğitim Bilimleri Enstitüsü Eğitim Programları Anabilim Dalında gerçekleştirilen yüksek lisans tezinin bir bölümünün özetidir.

${ }^{* *}$ Müdür Yardımcısı, Ankara-Çankaya Süha Alemdaroğlu Eğitim Uygulama Okulu ve İş Eğitim Merkezi, Ankara, Türkiye. E-posta: ozturkelcin80@gmail.com

*** Doç. Dr., Ankara Üniversitesi Eğitim Bilimleri Fakültesi Eğitim Programları Bölümü Ankara, Türkiye. E-posta: bikmaz@ankara.edu.tr
} 


\section{GíRiş}

İlköğretim bireyin gelecekte üstleneceği görev ve sorumluluklar için hazırlanmasına temel oluşturan bir öğretim kademesidir. Eğitim sistemimizde ilköğretim basamağı, resmi, özel ilköğretim okulu, taşımalı ilköğretim ve yatılı ilköğretim bölge okullarını (YİBO) kapsamaktadır.

Türkiye'de nüfusun dağınık yerleşimi, köyden kente göç sorunu nedeniyle özellikle küçük yerleşim birimlerinde nüfusun hızla azalması ve Karadeniz, Doğu ve Güneydoğu Anadolu bölgeleri gibi bazı bölgelerin coğrafi koşullarının yaşamı ve eğitime devamı olumsuz yönde etkilediği bilinmektedir. $\mathrm{Bu}$ durum, bu bölgelerde yaşayan ilköğretim çağındaki öğrencilerin eğitim talebinin merkezi bir eğitim kurumunda karşılanması çözümünü gündeme getirmiştir. Bu gerçeklerden hareketle, özellikle kalkınmada öncelikli yerleşim birimlerine yatılı ve gündüzlü öğretim veren YİBO'ların kurulması yoluna gidilmiştir (Aralpcan, 1998).

Nüfusu az ve dağınık yerleşim birimlerindeki çocuklar ile taşıma olanağı olmayan yerleşim birimlerindeki çocukların, ayrıca yoksul aile çocuklarının ilköğretim hizmetlerine kavuşturulması amacıyla eğitim öğretim imkânları YİBO'larla sağlanmıştır (MEB, 2007; Damğa, 2008). Bu öğrencilerin yiyecek, giyecek, kitap, kırtasiye, sağlık ve yatılılık gibi her türlü okul ihtiyaçları devlet tarafından karşılanmaktadır (Arı, 2002).

YİBO'lar 1961 yılında çıkarılan 222 sayılı İlköğretim ve Eğitim Kanunu ile 1973 yılında çıkarılan 1739 sayılı Milli Eğitim Temel Kanunu'na göre hazırlanan Bölge Okulları Yönetmeliği'nin

1. maddesindeki "Çeşitli sebeplerle henüz bir ilkokul açılmamış olup, birbirlerine yakın birkaç köyün bulunduğu yerlerde veya evleri ve ev grupları dağınık olan köylerde yatılı ilköğretim okulları açılır."

hükmü gereğince planlanarak açılmaya başlanmıştır. Daha sonra 1739 sayılı Milli Eğitim Temel Kanunu'nun 25. ve 222 sayılı İlköğretim ve Eğitim Kanunu'nun 9. maddesi çerçevesinde açılmaya devam edilmiştir (MEB, 2003). YİBO'lar gerek kuruluş amaçları ve gerekse içinde bulundukları durum açısından diğer kamu okullarından birçok yönüyle farklı1ıklar göstermektedir. MEB'e (2007, s:7-8) göre YİBO'ları diğer okullardan ayıran özellikler şöyledir:

1. YİBO'larda yaşam 7 gün 24 saat sürerken diğer okullarda bu süre hafta içi 6-8 saatle sınırlı kalmaktadır.

2. YİBO'lar çocuklara ilerleyen yıllarda gerekli olacak yaşam becerilerini de kazandırmayı amaçlayan okullardır.

3. Öğrenciler kalabalık olmayan sınıflarda ve iyi planlanmış kaynaklarla daha kaliteli eğitim alabilmektedir. 
4. Öğrenciler, öğretmenlere ve destek personeline her zaman ulaşabilmektedir.

5. Öğrenciler, kendi kendine güdülenebilmekte aynı anda çalışabilmektedir.

6. Öğrenciler, çalışırken öğretmenleri tarafından sürekli desteklenmektedir.

7. Öğrenciler, bağımsız iş yapabilmeyi, sorumluluklarını ve geleneksel değerleri öğrenmektedir.

8. Öğrenciler, ödevleri için daha fazla zaman ayırabilmektedir.

9.Öğrenciler, eğitim programı dışı etkinliklere katılarak zamanlarını daha verimli kullanabilmektedir.

9. Öğrenciler, parasını etkili kullanma, öz bakım becerileri kazanma gibi program dışı becerileri de kazanarak kendi kendine yetmeyi öğrenmektedir.

10. Öğrenciler, okuldaki yapılandırılmış yaşam biçimiyle daha iyi akademik başarı gösterebilmektedir.

11. Öğrenciler bir üst öğretim kurumunda parasız yatılı olarak öğrenimine devam edebilmektedir.

12. Öğrenciler, sürekli ve rutin bir ortamda bulunmakla kendilerini disipline edebilmekte ve gelecek için iyi çalışma alışkanlıkları kazanabilmektedir.

Türkiye'de 2009 - 2010 y1lı eğitim istatistiklerine göre farklı bölgelerde toplam 575 YİBO ve 247.376 öğrenci bulunmaktadır. Bu öğrencilerin 151.761 'i (61.801 k1z, 89.960 erkek) yat1l1 ve 95.615'i (46.633 kız ve 48.982 erkek) gündüzlü olarak öğrenim görmektedir (MEB, 2010).

YİBO'larda diğer ilköğretim okullarında olduğu gibi $1-5$. sınıflarda sınıf öğretmenliği esastır. Ancak, YİBO'lara özgü olarak yatılı öğrencilerin ders saatleri dışında eğitimleri ile ilgilenmek, öğrencilerin çalışma zamanında ve çalışma yerlerinde ders çalışmalarını sağlamak, çalışmaları sırasında karşılaştıkları güçlüklerin çözümüne yardımcı olmak üzere okul öğretmenleri veya ilköğretim-ortaöğretim kurumlarında öğretmenlik yapanlar arasından okul müdürünün önerisi, milli eğitim müdürünün uygun görmesi ve mülki amirin onay1 ile belletici öğretmenler görevlendirilmektedir.

Son yıllarda sayılarının ve olanaklarının artırılmasına yönelik çabalar sürmesine rağmen, YİBO'larda verilen eğitimin niteliğine, ekonomik ve fiziksel koşullarına ilişkin hizmetlerin yetersizliğine, toplumun bu okullara bakışına, personel ve öğrenci-veli iletişim sorunlarına ilişkin birçok sorun dile getirilmektedir (Işıkoğlu, 2007; MEB, 2002).

YİBO'larla ilgili yapılan araştırmalar incelendiğinde; çalışmaların ilköğretim okullarının sosyal etkilerinin değerlendirilmesi, YİBO'ların fiziksel olanakları (Aralpcan, 1998; MEB, 2002), ilköğretim 
uygulamalarının değerlendirilmesi (Ar1, 2002), YİBO'larda görevli öğretmen ve yöneticilerin stres kaynaklarının belirlenmesi (Gülbeyaz, 2006), öğretmenler ve yöneticilerin yaşadıkları sorunlar ve tükenmişlik düzeyleri (Gündüz, 2006; Özkaya, 2006), YİBO ve ilköğretim okullarının toplumsal fonksiyonlara ulaşabilme düzeylerinin belirlenmesi (K1lıç, 2001), YİBO uygulamaları ve sorunlarının araştırılması, YİBO'ların önemi ve farklı yönleri (MEB, 2008; MEB, 2007; Işı1koğlu, 2007; Ulusoy, 2006), öğrencilerin boş zaman alışkanlıkları, velilerin yaklaşımları (Çılğın, 2007; Karataş, 2006; Özgündüz, 2006), öğrencilerin temizlik alışkanlıkları (Altınsoy, 2008) gibi konular üzerine odaklanıldığı görülmektedir.

Araştırma sonuçları, yüklendiği misyon nedeniyle YİBO'larda eğitimin niteliğinin yükseltilmesi, eğitim ve barınma ortamlarının, sosyal, kültürel ve sportif faaliyetlerle ilgili ortamların yeterli, nitelikli hale getirilmesi, öğrencilerin istekle okula devamını sağlayacak ve aynı şekilde öğretmen ve yöneticilerin çalışma koşullarını da kolaylaştıracak şekilde oluşturulması veya var olanların iyileştirilmesinin gerekliliğini ortaya koymaktadır.

Eğitim reformlarının başarıya ulaşabilmesi için uygulayıcıları tarafından iyi anlaşılması ve eğitim ortamlarının reformun beklentileriyle uyumlu olması kaçınılmazdır. Fullan (1991) da kişilerin çalıştıkları kurum ya da ortamların sosyal koşullarının değişimi doğrudan etkilediğini belirtmektedir. Buna göre, okulların kendine özgü koşullarının arzulanan değişimleri hayata geçirme konusunda engeller ya da firsatlar sağladığını, bir programın aynı bölgedeki bir okulda başarılı bir başka okulda ise felaket olabileceğini belirtmektedir. Kin \& Chan (2010) ise eğitim politikalarının uygulamaya başarılı olarak yansıtılmasında okulların ve sınıfların gerçekleri ile reformların nasıl uyumlu hale getirileceğinin bu süreçte düşünülmesi gerektiğini belirtmektedir.

Gerek yasal düzenlemeler gerek alan yazın incelendiğinde, YİBO'ların kendilerine özgü eğitim ortamları ve çalışma koşulları olduğu açıkça görülmektedir. Ancak 2005 yılında geliştirilen ilköğretim programlarının, daha önceki yıllarda yapılan program geliştirme çalışmalarında da olduğu gibi okulların kendilerine özgü koşulları yeterince dikkate alınmadan tüm okullarda uygulanması kararlaştırılmıştır. Bu araştırma, eğitim ortamları ve çalışma koşulları açısından diğer ilköğretim kurumlarından farklı olan YİBO'larda görev yapan öğretmenlerin programı benimseme durumları, görev yaptıkları kurumdaki eğitim ortamlarının 2005 ilköğretim programlarına uygunluğu konusundaki görüşleri ve ilköğretim programlarının uygulanmasında karşılaşılan sorunlar ve çözüm önerileri diğer ilköğretim kurumlarında görev yapan sınıf öğretmenlerinden daha farklı olabileceği düşünülerek gerçekleştirilmiştir. 
Araştırma elde edilen verilerin program geliştirme ve programların uygulanmas1 konusunda MEB ilgililerine önemli katkılar getireceği düşünülmektedir. Ayrıca, YİBO öğretmenlerinin ilköğretim programlarının uygulanmasında yaşadıkları sorunlar belirlenerek onların hizmet içi eğitim ihtiyaçlarının belirlenmesine de yardımcı olunacağı umulmaktadır.

$\mathrm{Bu}$ araştırmanın genel amac1, YİBO'larda görev yapan sinıf öğretmenlerinin ilköğretim programları hakkındaki görüşlerini belirlemektir. Bu amaçla aşağıdaki sorulara cevap aranmıştır. YİBO'larda görev yapan sinıf ögretmenlerinin;

1. İlköğretim programlarını benimseme durumları nasıldır?

2. Görev yaptıkları okulların eğitim ortamlarının (fiziksel, sosyal, duyuşsal ve akademik) ilköğretim programlarına uygunluğu konusundaki görüşleri nelerdir?

3. İlköğretim programlarını uygulama konusunda yaşadıkları sorunlar ve bunlara ilişkin çözüm önerileri nelerdir?

\section{YÖNTEM}

\section{Araştırmanın Modeli}

YİBO’larda görev yapan sınıf öğretmenlerinin ilköğretim programlarına ilişkin görüşlerinin daha bütüncül ve derinlemesine ortaya konulabilmesi için verilerin toplanması, çözümlenmesi ve yorumlanmasında nitel araştırma modeli kullanılmıştır.

\section{Çalışma Grubu}

Araştırmanın çalışma grubunu, 2009-2010 öğretim yılında Çankırı'da bulunan yedi YİBO'da görev yapan onbeş sınıf öğretmeni oluşturmuş̧tur. Çalışma grubu oluşturulurken, Çankırı ilinde bulunan her YİBO'dan öğretmenlerin katılımının sağlanması düşünülmüştür. Ayrıca, ilköğretim programlarının uygulanmasında sınıf düzeyine özgü sorunlar olabileceği düşünülerek her sınıf düzeyini temsil etme durumu da dikkate alınmıştır. Çizelge 1'de çalışma grubuna dahil edilen öğretmenlerin bazı özellikleri verilmiştir. 
Çizelge 1. Çalışma grubunu oluşturan öğretmenlerin bazı özelliklere göre dağıllımı

\begin{tabular}{|c|c|c|c|c|c|}
\hline $\begin{array}{l}\text { Katılımeı } \\
\text { Kodları }\end{array}$ & Cinsiyet & Mezun olunan kurum & $\begin{array}{c}\text { Mesleki } \\
\text { deneyim } \\
\text { (yll) }\end{array}$ & $\begin{array}{c}\text { YíBO'daki } \\
\text { görev süresi } \\
\text { (yll) }\end{array}$ & $\begin{array}{l}\text { Okutulan } \\
\text { sinıf } \\
\text { düzeyi }\end{array}$ \\
\hline YK1 1.YİBO & Erkek & Uludağ Ün. Sınıf Öğretmenliği & 9 & 1 & 2. sinif \\
\hline YK2 1.YİBO & Erkek & Abant İzzet B. Ün. Sınıf Öğretmenliği & 8 & 2 & 5. sinif \\
\hline YK3 2. YIBBO & Kadın & 19 Mayıs Ün. Sınıf Öğretmenliği & 3 & 1 & 4. sinif \\
\hline YK4 2.YİBO & Kadın & Kırıkkale Ün. Sınıf Öğretmenliği & 4 & 3 & 3. sinif \\
\hline YK5 3.YİBO & Erkek & Ankara Ün. Ziraat Mühendisliği & 13 & 2 & 3. sinif \\
\hline YK6 3.YİBO & Erkek & Çankırı Eğitim Enstitüsü & 30 & 2 & 5. $\sin 1 f$ \\
\hline YK7 4.YİBO & Kadin & 19 Mayıs Ün. Sınıf Öğretmenliği & 7 & 2 & 3. sinif \\
\hline YK8 4.YİBO & Erkek & Gazi Ün. Sınıf Öğretmenliği & 7 & 1 & 2. sinif \\
\hline YK9 4.YİBO & Erkek & Pamukkale Ün. Tarih Öğretmenliği & 9 & 4 & 4. sinif \\
\hline YK10 5.YİBO & Erkek & İnönü Ün. Sınıf Öğretmenliği & 6 & 1 & 1. $\sin 1 f$ \\
\hline YK11 5.YİBO & Erkek & Kastamonu Eğitim Yüksek Okulu & 23 & 5 & 2. $\sin 1 f$ \\
\hline YK12 6.YİBO & Erkek & Cumhuriyet Ün. Kimya Bolumu & 14 & 7 & 1. $\sin 1 f$ \\
\hline YK13 6.YİBO & Kadın & Kırıkkale Ün. Sınıf Öğretmenliği & 7 & 7 & 4. $\sin 1 f$ \\
\hline YK14 7.YİBO & Kadın & Marmara Ün. Kimya Öğretmenliği & 5 & 3 & 1. sinif \\
\hline YK15 7.YİBO & Kadın & Süleyman D. Ün. Sınıf Öğretmenliği & 10 & 6 & 5. $\sin 1 f$ \\
\hline
\end{tabular}

Öğretmenlerin büyük çoğunluğunun sınıf öğretmenliği bölümünden mezun olduğu ve mesleki kıdemlerinin 4 ila 30 yıl arasında değiştiği görülmektedir. Öğretmenlerin YİBO'da çalışma süreleri incelendiğinde ise bu sürenin 1 ile 7 yıl arasında değiştiği ve çalışma grubunda her sınıf düzeyini okutan öğretmenlerin bulunduğu görülmektedir. Ayrıca öğretmenlerin tamamının değişen programlar konusunda seminer aldıkları, hiç birinin lisansüstü eğitim derecesine sahip olmadığı da belirlenmiştir.

Araştırma etiği çerçevesinde görüşmelerin yapıldığı okul veya ögretmenler ile ilgili hiçbir kurumsal bilgi ve isim verilmemiş, sadece verilerin incelenmesinde kolaylık sağlamak amacıyla Çizelge 1'de verilen çeşitli kodlar kullanılmıştır. Buna göre örneğin; YK1; YİBO'da görev yapan 1 no'lu olarak kodlanan sınıf öğretmenini göstermektedir.

\section{Veri Toplama Araç ve Teknikleri}

Araştırmanın verileri yarı yapılandırılmış görüşmeler yoluyla toplanmıştır. YİBO 1-5. sinıflarda görev yapan sınıf öğretmenlerinin ilköğretim programlarına ilişkin görüşlerini belirlemek üzere, araştırmacı tarafindan açık uçlu sorulardan oluşan görüşme formu taslak olarak hazırlanmıştır.

Görüşme sorularının kapsam geçerliliğini sağlamak amacıyla araştırmanın her alt amacı için birden fazla soru yazılmış, program geliştirme ve ölçme değerlendirme bilim dalında görevli sekiz uzman ile ilköğretim okullarında görevli beş sınıf öğretmeninin görüşleri alınmıştır. Uzmanlardan hazırlanan sorulardan araştırma amaçlarına en uygun olan soruları belirlemeleri ya da varsa kendi önerilerini yazmaları istenmiştir. Görüşme soruları uzman görüşleri doğrultusunda tekrar düzenlenmiştir. 
Görüşme süresinin ve alınan yanıtların araştırma sorularına tam olarak cevap olup olmadığının belirlenmesi amacıyla iki sınıf öğretmeni ile deneme görüşmeleri yapılmıştır. Elde edilen dönütler 1şığında görüşme soruları tekrar incelenerek dil, ifade ve kapsam açısından son şekli verilmiştir.

\section{Verilerin Toplanması}

Görüşme yapılan her okulun yöneticisiyle görüşmelerin içeriği konusunda ön görüşmeler yapılmış ve araştırmanın amacı açıklanarak gerekli izinler alınmıştır. Görüşmeler öncesinde öğretmenlere, araştırmanın amacı ve görüşme süreci hakkında gerekli açıklamalar yapılmıştır. Araştırma verileri birinci araştırmacı tarafından toplanmış ve katılımcılarla yüz yüze gerçekleştirilen görüşmeler onların onayları alınarak ses kayıt cihazıyla kaydedilmiştir. Görüşmeler ortalama 40 dakika sürmüştür.

\section{Verilerin Analizi}

Araştırmada elde edilen veriler, nitel analiz yöntemlerinden içerik analizi yöntemi ile analiz edilmiştir. İçerik analizi, sözel, yazılı ve diğer materyallerin içerdiği mesajı anlam ve/veya dilbilgisi açısından nesnel ve sistematik olarak sınıflandırma, sayılara dönüştürme ve çıkarımda bulunma yoluyla sosyal gerçeği araştıran bilimsel bir yaklaşımdır (Tavşancıl ve Aslan, 2001).

Araştırmaya katılan öğretmenlere ait görüşler araştırmanın soruları doğrultusunda analiz edilerek kodlanmıştır. Kodlanan veriler araştırmaya katılan öğretmenlerin konuşma metinleriyle desteklenmiştir.

Araştırmanın güvenirliğinin sağlanması için verilerin kodlanmasındaki tutarlılık incelenmiş̧ir. Görüşmeler çözümlendikten sonra, belirli bir bölümü bir başka araştırmacı tarafindan da kodlanmıştır. Araştırmacılar arasındaki uyum "Güvenilirlik = Ortak kodlama sayısı / ortak kodlama + ortak olmayan kodlama sayısı x 100" formülüne göre hesaplanmış ve kodlama güvenirliği \%86,36 olarak bulunmuştur. Miles \& Huberman (1994), uyuşum yüzdesinin en az \%80 olmasının gerektiğini belirttiklerinden, bu oran yeterli görülmüştür.

\section{BULGULAR}

\section{YİBO'larda Görev Yapan Sınıf Öğretmenlerinin İlköğretim Programlarını Benimseme Durumuna İlişkin Bulgular}

YİBO'larda görev yapan on beş sınıf öğretmenin programı benimseme durumlarını belirlemek amaciyla, program tercihleri ve memnuniyet 
düzeyleri ile ilgili sorular yöneltilmiştir. Buna göre oniki sınıf öğretmeni 2005 programını tercih ettiklerini belirtmişlerdir. Programın öğrenci merkezli olmasını, öğrencinin sürece aktif şekilde katılmasını, öğrencinin daha kolay öğrenmesini, uygulamaların kalıcı bilgi sağlamasını, öğrencinin araştırma becerisi kazanmasını, öğrenme sürecini eğlenceli hale getirmesini 2005 programını tercih etme nedenleri arasında göstermişlerdir.

Öğretmen $\left(\mathrm{YK}_{15}\right)$, öğrencinin daha kolay öğrendiğini, yeni programla öğrenme sürecinin eğlenceli hale geldiğini ve kılavuz kitapların işlevsel olduğunu şöyle belirtmiştir:

"Bu program birçok noktada somutlaştırma yaptığı için öğretmenin ekstra düşünmesini biraz azaltıyor, bu da çocuklara vereceğiniz enerjiyi arttırıyor doğal olarak. Bir kere bu açıdan çok yeterli. İkincisi kazanımların niteliği, kazanımların azaltılmış olması öğrenciler açısından öğrenmede, uygulamada kolaylık sağlıyor. Bunun dışında kılavuz kitapların olması ve bizi o kâğıt işlerinden kurtarmış olması yine öğretmen açısından çok kolay. Eğitim öğretim sürecini sanki biraz daha eğlenceli hale getirdi diye düşünüyorum. Mesela ben çok keyif alıyorum. Eski programı uygularken matematik dersini anlatırken panik yaşardım aslında. Nasıl yapsam, nasıl anlatsam daha iyi anlatırım diye. O açıdan öğretmenin yükünü biraz hafiflettiğini düşünüyorum."

2005 y1lı öncesindeki programı tercih ettiklerini belirten öğretmenler ise, önceki programda ders kitaplarının içerik olarak daha dolu olması, öğrencilere temel bilgileri vermesi ve okuma yazma öğretim yönteminin daha işlevsel olmasını tercih nedenleri olarak göstermişlerdir.

Öğretmen $\left(\mathrm{YK}_{8}\right)$, programda bilgi eksikliği olduğunu, bu durumun sıkıntı yarattı̆̆ını, bu nedenle eski sistemdeki gibi öğretmenin de merkezde olması, bilgi eksikliğini tamamlaması gerektiğini 2005 yılı öncesindeki programı tercih etme nedeni olarak belirtmiştir:

"... Sadece öğrenci merkezli olmasın istiyorum. Zaten bakanlık da bunun farkına vardı ki zaman zaman gönderdiği yazılarda tamamen hazırcılığa dayandığı, internet ortamından kopyalandığına kadar bununla ilgili yazı gönderir hale geldi. $\mathrm{Bu}$ eksikliği kendileri de gördüler diye düşünüyorum artık. Bazı şeyleri de öğretmenin muhakkak vermesi gerekiyor. Öğretmenin de zaman zaman ortaya çıkıp öğretmen merkezli ders anlatması, bilgi vermesi gerektiği kanısındayım.”

Araştırmaya katılan öğretmenlerden 2005 y1lı öncesinde uygulanan programı ve 2005 programını harmanlamayı tercih edeceğini belirtmiş olanlar ise, içerik boyutu ve okuma yazma öğretim yöntemi açısından önceki programı daha etkili bulduklarını vurgulamışlardır. Öğretmen $\left(\mathrm{YK}_{2}\right)$, görüşünü şöyle dile getirmiştir:

"Bu konuda ilginç bir şey söyleyeyim ben. Müfettişimiz geldi. Şiir defteri tutturuyoruz, şiir yazdırıyorum, dik temel harflerle yazdırıyorum. Müfettiş eleştirdi. Hocam haklısınız dedim, programın emrettiğini de biliyorum ama çocuklar okumada, yazmada sıkıntı çekiyor, ben bunu da vermek zorundayım dedim. Bu kitap da dik temel harflerle. Sonradan o da hak verdi. Şimdi eski müfredat da tamamen kaldırılmış değil. Yeni müfredatta tamamen farklı bir 
müfredat değil. İkisinin de güzel yanları var. Ben ikisini karma yaparım işin gerçeği."

YİBO'larda görevli sınıf öğretmenlerine 2005 programı ile ilgili memnuniyet durumları sorulduğunda, on sinıf öğretmeninin programdan memnun olduğu; beș sınıf öğretmeninin ise programı bazı yönleriyle beğendikleri ve uygulanabilir buldukları, ancak programın bazı eksik yönleri olduğunu belirterek kısmen memnun olduklarını belirttikleri görülmüştür. Öğretmen $\left(\mathrm{YK}_{15}\right)$, öğrencinin bilgiye kendinin ulaştığını, eğlenerek öğrendiğini belirtmiş, programdan çok memnun olduğunu söylemiştir:

'Programdan çok memnunum. Uygulama açısından güçlük çekmiyorum. Çocuklar çok keyif alıyorlar. Eğlenerek öğreniyorlar. Şu var çocuklara bir şeyleri veriyorsunuz, kendileri buluyor, asıl olanı kendileri buluyor bu çok güzel. O yüzden ben memnunum."

Öğretmen $\left(\mathrm{YK}_{10}\right)$, veli boyutu hariç programdan memnun olduğunu belirtmiştir:

"İnşallah olumlu yönde sonuçlar ortaya çıkar ve program devam eder. Söylediğim gibi tabii ki eksiklik var konuyla ilgili, veliyle ilgili onları da ben kendim ortadan kaldırmaya çalışıyorum... Ben bu programdan, okulumdan, süreçten, öğrencilerimden memnunum. Veliler hariç.”

Araştırmaya katılan YİBO'larda görev yapan sınıf öğretmenlerinin 2005 ilköğretim programını tercih nedenleri ve programdan memnuniyet durumları birlikte ele alındığında, bazı olumsuz görüşlerle birlikte ilköğretim programlarını büyük ölçüde benimsedikleri söylenebilir.

\section{YİBO'larda Görev Yapan Sınıf Öğretmenlerinin Eğitim Ortamlarının İlköğretim Programlarına Uygunluğu Konusundaki Görüşleri}

\section{Fiziksel Ortamların Uygunluğu}

YİBO’larda görevli sınıf öğretmenlerinin tamamı, 2005 programının etkili ve verimli bir şekilde uygulanabilmesi için kurumlarında öğretmen sayısı ve idari kadro açısından bir sıkıntı yaşanmadığını belirtmiştir. Bunun yanı sıra, öğretmenlerin bir kısmı, fiziksel donanımın yetersiz olması ve bulundukları çevrenin koşullarından dolayı sıkıntılar yaşadıklarını ifade etmişlerdir. Öğretmen $\left(\mathrm{YK}_{1}\right)$, kurumlarında fiziksel donanımın yetersiz olduğunu şöyle belirtmiştir:

"Kütüphanemiz, bilgisayar odamız, projeksiyon odamız var. Eğitim CD’leri var. Ama kullanım açısından çok da kullanıldığını söyleyemem. Mesela müzik odamız vardı, geçen yıl bir müzik öğretmenimiz vardı. Ama odada masa, sandalye, sıra vardı. Başka bir şey yok. Öğretmen arkadaş kendi imkânlarıyla bir org almış. Bu okulda bir piyano, üç dört tane keman olmalı, bir iki tane saz olmalı..."

Öğretmen $\left(\mathrm{YK}_{9}\right)$, görev yaptığı kurumun fiziksel donanımının yetersiz olduğunu şöyle belirtmiştir: 
"Fiziki olarak biz çok kötü bir okul değiliz ama çok iyi bir okul da değiliz. Her sınıfta bir bilgisayar yok mesela. Bilgisayarlık, projeksiyonluk bir işimiz olduğu zaman sınıflarımıza kendi bilgisayarlarımızı götürüyoruz, kendimiz kuruyoruz sürekli taşımayla, büyük ölçüde kendi kişisel imkânlarımızla. Bilgisayar laboratuvarları yeterli değil. 10 yıl önce kurulmuş YİBO'ya bilgisayar laboratuvarları. $\mathrm{Bu}$ mevcut bilgisayarlar çocukların araştırması için de yeterli değil. 10 yıldır da bu bilgisayarlar deforme olmuş yani. Özellikle kırsal bölgelerde bunlar hızl yenilenemiyor."

Öğretmen $\left(\mathrm{YK}_{7}\right)$, kurumun fiziksel donanımının yetersiz olduğunu ve YİBO'larda öğrenim gören öğrencilerin ders araç gereçlerini teminde sıkıntı yaşadıklarını belirtmiştir.

"Artık eğitim ortamlarında bilgisayar ve projeksiyon şart diyorum. Artı kırtasiye kısmı çok şart. Kimin nasıl sağlayacağını bilmiyorum ama biz bu yıl velilerimizden yardım aldık, ihtiyaç listemizi yazarken biraz fazla istedik malzemeleri, karton, el işi kağıdı, yapıştırıcı, makas vb. etkinliklerde çok fazla bu tür araçlar kullanılıyor. Okulumuza da geliyor kırtasiye malzemeleri ama her seferinde o kadar öğrenciye yetecek kadar olmuyor."

Öğretmen $\left(\mathrm{YK}_{12}\right)$ ise görev yaptığı kurumun fiziksel donanımının yeterli olduğunu, YİBO'larda çalışmanın bazı imkânlar sağladığını, ancak ders araç gereçleri, materyal temini konusunda çevresel koşulların yetersiz olduğunu belirtmiştir.

"YİBO'lara herhalde kaynak olarak para aktarımı biraz daha fazla. Bir malzemeyi almak istediğimizde öyle bir imkânımız var. Örneğin büyük bir araç gereç almak istediğimizde burada bulamıyoruz. Nereden getireceğiz, Çankırı merkezden getirteceğiz. Ben şimdi birinci sınıflara okumayla ilgili kitaplar, seri aldırdım. ... Okullar açıldı hala elime ulaşmadı. Böyle imkânsızlıklar var işte. Diğer yönden mesela projeksiyonmuş, bilgisayarmış, laboratuvarmış her türlü imkânımız var."

\section{Sosyal Ortamların Uygunluğu}

YİBO sınıf öğretmenlerinin görev yaptıkları okulun sosyal ortamlarının ilköğretim programlarına uygunluğu konusundaki görüşleri incelendiğinde, öğretmenlerin önemli bir bölümü (12 öğretmen) 2005 programının etkili ve verimli bir şekilde uygulanabilmesi için ihtiyaç duyulan sosyal ortamın kurumlarında sağlandığını, öğretmenler arası ve okul yönetimi ile uygulamalara yönelik işbirliği yapılabildiğini belirtmişlerdir. Bununla birlikte, üç ögretmen okul yöneticilerinin programa ilişkin bilgi eksikliği nedeniyle ögretmenler arası ve okul yönetimiyle iletişim ve işbirliğinde sıkıntı yaşandığını belirtmişlerdir.

Öğretmen $\left(\mathrm{YK}_{9}\right)$, görev yaptığı okulun sosyal ortamının destekleyici olduğunu şöyle ifade etmiştir:

"Eski programda her sınıfın bir öğretmeni veya bazı köy okullarında birleştirilmiş sınıflar vardı. Bunların etkileşimi ile işler yürüyordu ama şimdi ben sınıf öğretmeniyim, benim bir fen bilgisi öğretmeniyle, sosyal bilgiler öğretmeniyle 
işim olmaz diye bir şey kalmadı. Tam tersine okuldaki bütün öğretmenleri bir zincir gibi birbirine bağladı program... Okulumuzda öğretmenlerle, yönetimle iletişim, etkileşim, bilgi alışverişi iyi. Bizim YİBO olarak avantajımız, hepimiz birbirimize yakınız, bağlıyız. 24 saat birbirimizi görme imkânımız var."

Öğretmen $\left(\mathrm{YK}_{1}\right)$ ise, görev yaptığı okulun sosyal ortamının destekleyici olmadığını söylemiştir:

"Ortamı güzelleştirmek, ortamı cazip hale getirmek, ilişkileri sıkı tutmak, kişisel problemler olur, kurum içi ters düştüğümüz noktalar olabilir ama ne olursa olsun amaç aynı. Burada önemli olan öğrencinin en iyi eğitimi alması, en iyi şekilde yetişmesi. Herkes birbirine destek olmalı, destek olmuyorsan köstek olmamak lazım. Okulumuza gelirsek, bu söylediklerimin üzerine eksi bir, yani tam tersi. Burada onu göremedim. İletişim, etkileşim sağlanamıyor. Bağlantı kopukluğu var."

\section{Duyuşsal Ortamların Uygunluğu}

Araştırma kapsamına alınan YİBO'ların duyuşsal ortamlarının ilköğretim programlarına uygunluğuna ilişkin öğretmen görüşleri değerlendirildiğinde, on iki sınıf öğretmeni kendini çalıştığı okula ait hissettiğini, üç sınıf öğretmeni ise kendilerini çalıştıkları okula ait hissetmediklerini ve bu durumun da performanslarını olumsuz yönde etkilediğini belirtmişlerdir. Öğretmen $\left(\mathrm{YK}_{8}\right)$, görev yaptığı kuruma kendisini ait hissettiğini belirtmiş, ancak YİBO'da görev yapan öğretmenler için çevresel koşulların çok önemli olduğunun altını çizmiștir:

"Çalışma ortamı olarak okulda mutluyum diyebilirim. Fakat bizim burada mutluyuz diyebilmemiz için en önemli kriter çevre oluyor, ihtiyaçlarımızı yeterli derecede karşılayabilmek."

Öğretmen $\left(\mathrm{YK}_{15}\right)$, çalışma koşulları nedeniyle YİBO'da çalışmaktan memnun olmadığını, bu sebeple kendini çalıştığı kuruma ait hissetmediğini belirtmiştir:

"Özel olarak sınıfımı seviyorum. Sınıfımla ilgilenmekten memnunum. Ama okul, çevre şartları, ortam açısından değerlendirildiğinde okulda çalışmaktan çok memnun olduğumu söyleyemem."

Öğretmen $\left(\mathrm{YK}_{4}\right)$ ise düşüncelerini şöyle özetlemiştir:

"Sıkıntılar yaşadık tabii, uzun süre kendimi ait hissedemedim. Belki birçok arkadaşım da hissedemiyor. Neden diyeceksiniz. Tabii ki sıkıntıları var normal bir okula göre. ... Yatılı bir okul olması sebebiyle nöbet, belleticilik görevimiz var. Bu görev süresince aldığımız sorumluluk, koşuşturmaca da bizi yoruyor elbette. Ertesi günde o şekilde derse girmek bir handikap, çok verimli olamıyoruz tabii ki. ... Özellikle birinci sınıfta veli desteği çok önemli. Çocuklar uzun süre psikolojik açıdan zorluk yaşıyorlar, ilk bir-iki ay yatılı bir okula alışmakta zorluk çekiyorlar, duygusal gelgitler yaşıyorlar. Tabii onlara da ayrı bir şefkat, ekstra bir ilgi göstermeniz gerekiyor. Ayrıca çevrede genellikle ekonomik-sosyal açıdan düşük ailelerin çocukları oldukları için yatılı okul öğrencileri birçok temel becerilere de sahip olamayabiliyorlar. Bu konularda da sıkıntı çekilebiliyor. ... Ama güzel yönü 
ne derseniz, onlarla çok iç içe olduğunuz için sizi çok farklı benimsiyorlar, sizi bir yakını gibi görüyorlar, siz de onları bir yakınınız gibi görüyorsunuz zamanla. ... Birlikte yaşıyorsunuz, birlikte yatıyorsunuz, yemek yiyorsunuz, gününüzü birlikte geçiriyorsunuz, ateşi çıktığında belki sabaha kadar başında bekliyorsunuz gibi sebeplerle normal bir okula göre de onlarla çok daha yakın olabiliyorsunuz. Mesleki anlamda da bu şekilde bir doyuma ulaşabiliyorsunuz diyebilirim.”

\section{Akademik Ortamların Uygunluğu}

YİBO'larda görevli sınıf öğretmenlerinin büyük çoğunluğu (11 öğretmen) ilköğretim programının etkili ve verimli bir şekilde uygulanabilmesi için ihtiyaç duyulan akademik desteğin kurumlarında yeterli düzeyde sağlanamadığını belirtmişlerdir. Öğretmen $\left(\mathrm{YK}_{3}\right)$, görüşünü şöyle ifade etmiştir:

"Seminerler, kurslar falan merkezde olduğu için tabii sorun oluyor merkeze gitmek gelmek. İlçede açılan kurslar, seminerler olduğu zaman tabii ki faydalaniyoruz ama biraz sorun var tabii."

Öğretmen $\left(\mathrm{YK}_{7}\right)$, akademik anlamda desteğin yetersiz olduğunu belirtmiştir:

"Seminer döneminde sunular gönderildi, sunularımız vardı izledik, ama yeterli gelmiyor bence. Dediğim gibi kurslar, seminerler, yani kendimiz değil dişarıdan bu işi gerçekten yapmış, öğrenmiş, araştırmış, eğitimini almış kişilerin yapması. Ben aktif öğrenme kursuna gittiğim zaman öğretmenliğimin ikinci yılıydı. Çok bilinçli değildik o dönem belki de. O dönemde CD’lere falan çekmiştik. Şimdi CD’leri izlediğimde birçok tekniği öğrenmişiz orada. Orada öğrendiğimiz teknikleri çok rahat kullanabiliyoruz."

Öğretmen $\left(\mathrm{YK}_{6}\right)$, seminerlerin genelde hafta sonlarında ve zorunlu olduğunu, bu uygulamanın verimli olmadığını belirtmiştir:

"Şimdi yer yer açılması gereken seminerler oluyor, onları gönderiyorlar. Bazı seminerler amacına da ulaşmıyor bana göre. Meslek yönünden bana gerekli olan dokümanları araştırıyorum, inceliyorum. Bir hazırlık yaparak, mutlaka en derin bir şekilde çalışmak için uğraşıyorum. Ama tabii ki bir öğretmenin kendini geliştirmesi için o seminerlere de ihtiyacı var. O seminerler genellikle eğitim ögretim yılı içinde açıllyor, bu da benim için pek olumlu değil. Öğretmenin boş zamanında veya eğitim öğretimin dı̧ında farklı yerlerde verilse daha faydalı olacağını düşünüyorum. Çoğu seminerlere biz hafta sonu katıldık. Hafta sonu zoraki getirildik. Burada da zoraki olduğu zaman verim olmuyor."

Öğretmen $\left(\mathrm{YK}_{9}\right)$, akademik anlamda desteklenmeye ihtiyaç duyduğunu ifade etmiştir:

"Tabii ki elimizden geldiği kadar kendimizi geliştiriyoruz. Artık yeni bir öğretmen benden daha fazla deneyimli, çünkü üniversite olarak da yeni programa göre eğitim alıyor. Bizim bunları yakalamamız lazım. ... Özellikle yeni, son birkaç yılda işe başlamış öğretmenlerden öğrenecek çok şeyimiz var bence.” 
Öğretmen $\left(\mathrm{YK}_{15}\right)$, akademik anlamda yeterli desteğin olmadığını, bireysel anlamda çaba gösterdiğini, ancak YİBO'nun şartları nedeniyle bu çabanın da sınırlı düzeyde kaldığını belirtmiştir:

“Benim YİBO'da altıncı yılım. Bunun etkisinin büyük olduğunu düşünüyorum. Çünkü altı yıldır o yoğun iş temposunu sürekli yaşamış olmam çok etkili. Bunun dışında kendimi çok fazla geliştiremeyeceğimi düşünüyorum. Yani zaman zaman bilgilerimin köreldiğini çünkü kırsal kesimde aktarabileceğiniz ya da öğrencilerinize vermek istediğiniz bazı şeyleri sınırlandırmak zorunda kalıyorsunuz. Bunun sıkıntısını çekiyorum. Bireysel anlamda çabalarım oldu. Okuluma söylediğim zaman tabii ki desteklerini görüyorum ama yeterli değil."

\section{YİBO'larda Görev Yapan Sınıf Öğretmenlerinin İlköğretim Programını Uygulama Konusunda Yaşadıkları Sorunlar ve Çözüm Önerilerine İlişkin Bulgular}

YİBO'larda görev yapan sınıf öğretmenlerinin 2005 programının uygulanmasında yaşadıkları güçlüklere ilişkin görüşleri incelendiğinde; YİBO öğretmenlerinin çoğunluğu, öğretmen kaynaklı güçlük yaşamadıklarını belirtmişlerdir. Öğretmenlerin çok azı ise çalışma koşullarının, öğretmenler arası işbirliğini engellediğinin altını çizmişlerdir. Öğretmenler işbirliğini engelleyen nedenler olarak; öğrencilerin ailelerinden uzakta sürekli okulda kalmasını, 24 saat süren nöbet tutma sistemini, okulların kırsal bölgelerde bulunmasını ve çalışma koşullarının ağırlığını göstermişlerdir.

Öğretmen $\left(\mathrm{YK}_{3}\right)$, YİBO'ların çalışma koşulları nedeniyle öğretmenler arası işbirliğinin sağlanamadığını belirtmiştir:

"Okulumuzun ortamı yatılı okul olduğu için daha çok sorun yaşanıyor öğrenciler, idare, öğretmenler arasında. Çünkü nöbetler var özellikle sorun olan, yani sürekli sorun çıaran öğrenciler olduğu için sorun yaşanıyor bence. Nöbetlerde öğrencileri sürekli gözetim altında tutmak, ilgilenmek lazım. Bir sürü öğrenci olduğu için, öğretmen sayısı az olduğu için ve nöbetler çok yorucu bir şey olduğu için ögrretmenler arasında iletişimde de sorun olabiliyor, nöbetleri tutmak istemiyoruz."

Öğretmen $\left(\mathrm{YK}_{15}\right)$ ise konuya ilişkin görüşünü şöyle belirtmiştir:

"Bilgi alışverişi yapma konusunda hiç sıcak bir ortam yok. Onun dışında okulumuzun çok yoğun olması, yoğun bir temposunun olması, sosyal ilişkileri biraz zayıflatıyor. Çünkü herkes bir şekilde kendi sınıfı, nöbeti gibi durumlarla ilgilenmek durumunda kalabiliyor. Özel vakitlerimiz çok olamıyor. Bu tamamıyla kişisellikten değil, okul şartlarından, okulumuzun çalışma temposunun yüksek olmasından kaynaklanıyor."

YİBO'larda görevli sınıf öğretmenlerinin çok azının programın uygulanması sürecinde yönetici desteğini yetersiz buldukları, yöneticilerin 
2005 ilköğretim programlarına ilişkin yeterli düzeyde bilgilenmediklerini belirttikleri görülmüştür.

Öğretmen $\left(\mathrm{YK}_{3}\right)$, yönetici desteğinin yetersiz olduğunu, ancak bu durumun YİBO'nun şartlarından da kaynaklandığını vurgulamıştır:

"Genel olarak idareyle işbirliğinde bulunuyoruz ama yeterli değil. Ancak tabii ortada sorun olduğu zaman özellikle öğrenciyle, yurtla ilgili ögretmenden kaynaklanan bir sorun varsa tabii ki sıkıntı yaşanıyor. Çünkü YİBO öğrenci öğretmen, yönetici iletişimine daha çok önem verilmesi gereken bir okul. Daha çok kontrol edilmesi gerekiyor, takip edilmesi gerekiyor öğrencinin. Başarısızlık durumlarında falan sorun yaşanabiliyor tabii ki."

Öğretmen $\left(\mathrm{YK}_{2}\right)$, programı uygulamaya yönelik okul yöneticileri tarafindan yeterince desteklenmediklerini ifade etmiştir:

"Bence idare yeterli bilgiye sahip değil. Biz sizi destekleriz diyorlar. Sınıf içi materyallerin temini olsun, kitap temini olsun vs. Neyse bildirin biz yaparız diyorlar. Normalde bu tür konularda önce idare bilgilenir sonra öğretmeni bilgilendirir. Genelde önce öğretmen bilgileniyor, sonra idare bilgileniyor. Müfredata baktığımız zaman bence bir idarecinin sene başında oturup bütün yaz tatilinde veya belli seminerler şeklinde verilmesi gerekiyor, müfredatı incelemesi gerekiyor."

YİBO öğretmenleri, velilerin ilgisizliği nedeniyle programı uygulamada güçlükler yaşadıklarını belirtmişlerdir. Öğretmen $\left(\mathrm{YK}_{5}\right)$, görüşünü şu sözlerle belirtmiştir:

"Velilerimiz genelde kırsal kesim olduğu için duyarsız. Çağırıldığı zaman gelmiyorlar. Mesela benim rehber öğretmenle görüşmesi gereken velilerim var ama hiç gelmiyorlar. Bu tür sıkıntılar yaşıyoruz. İlgisizlik diyelim.”

Öğretmen $\left(\mathrm{YK}_{12}\right)$, velilerin ilgisizliği nedeniyle eğitim öğretim sürecinde yaşanan sıkıntıların altını çizmiştir:

"Benim birinci sınıfta birkaç öğrencim var mesela velisini çağırıyoruz gelmiyorlar. Telefon ediyoruz evde kimse çıkmıor. Bir de şu var bizim burada nöbetlerimiz olduğu için evlere de gitme şansımız olmuyor. Gideceğiz şimdi anne baba evde bulunmayacak. Gelsinler öğrencinin genel durumu hakkında konuşalım diyorum. Eve gidiyor ödevi yapamıorum diyor öğrenci, yazıyorum bunu okuyacaksın diyorum okuyamıorum diyor öğrenci. İlgilenen kimse yok velilerden. Çünkü uzak köylerden geliyor öğrenci. Bazı gündüzlü öğrencilerin velileriyle, bilinçli velilerle çarşıda, köye gittiğimde görüş̧ebiliyoruz. Bir sorun olduğu zaman tel ile de arıyorlar. Gündüzlü velilerimiz duyarlı. Yatılı velilerimizde duyarsız değil ama nedense gelemiyorlar. Görüşme imkânımız yok."

Öğretmen $\left(\mathrm{YK}_{15}\right), \quad$ YİBO'da veli desteğinin eksikliğini şöyle belirtmiştir:

"Şimdi yeni program veliyi işin içine katın diyor. Örneğin performans ödevlerinde, proje ödevlerinde, çocuğun öğrendiklerini evde uygulaması açısından veliyi işin içine katın diyor fakat YİBO'da olmamızdan dolayı veliyi işin içine çekemiyorsun. Tabii çekebildiğin bir kısım olabiliyor. Şimdi çocuklara evde yapılabilecek ev etkinlikleri vermek durumunda kalıyorsunuz bazı hafta sonu gidemedikleri için kendi başlarına yapmak durumunda kalıyorlar. Eğer ben o hafta 
sonu orada olursam ben desteklemek durumunda kalıyorum. ... Yani her türlü şeyi de denedik aslında. Okul yönetimi olarak da ev ziyaretlerimiz oldu, toplantılar yaptık, ben bireysel anlamda kendi ögrenci velilerimle de toplantılar yaptım ama bir kısmını ikna edemedim."

YİBO öğretmenlerinin çoğunluğu, 2005 programını anlamayla ilgili bir sıkıntı yaşamadıklarını belirtmişlerdir. Programı anlamayla ilgili güçlük yaşadığını belirten öğretmenler ise, program değişikliğine ilişkin yeterince bilgilendirilmediklerinin altını çizmişlerdir. Öğretmen $\left(\mathrm{YK}_{9}\right)$, programın eğitim çalışanlarına yeterince anlatılmadığını ifade etmiştir:

"Türkiye şartları düşünüldüğünde birkaç eksik dışında programın çok da eleştirilecek bir yönü yok. $\mathrm{O}$ da tabii ki uygulamada eğitim eksikliği boyutu var. Öğretmen olarak belli yerlerde biz belki eksik kalıyoruz. Evet, yani biraz daha fazla bilgilenilebilirdi. Kurs düzenlenebilirdi. Sanki birazcık aceleye geldi gibi."

Öğretmenlerin programı uygulama konusunda yaşadıkları sorunlara yönelik çözüm önerileri incelendiğinde, velilerin, öğretmenlerin ve yöneticilerin program hakkında bilgilendirilmesi, hizmet içi eğitimlerin akademisyenler veya uzmanlar tarafından verilmesi, okulöncesi eğitimle öğrencilere ön becerilerin kazandırılması, okulların fiziksel imkânlar, sosyal imkânlar, araç gereç, materyal açısından iyileştirilmesi ve yatılı öğrenciler için eğitim ortamının yapılandırılması gerektiğini önemle belirtmişlerdir. Ögretmen $\left(\mathrm{YK}_{2}\right)$, YİBO'lar açısından durumu yansıtmış, sorunlara yönelik çözüm önerilerini şöyle dile getirmiştir:

"Burası yatılı bölge okulu. Burada hem yatılı kalan öğrenciler var, hem köylerden taşımalı gelen öğrenciler var hem de ilçeden gelen öğrenciler var ve yatakhanemiz okulun içerisinde. Bence bu müfredatta bizim hedefe ulaşabilmemiz için yatakhanenin başka bir binaya geçmesi gerekiyor. Çünkü çocuk orada yatıyor kalkıyor, geliyor. Köyden gelen öğrenci 6'da kalkıyor, kahvaltı yapmış derse girdiğinde zaten açıkmış oluyor. ... Köyden gelen öğrenci ile merkezden gelen öğrencinin seviyesi farklı. Yatılı kalan öğrencinin durumu farklı. ... Bir şeye karar vermemiz gerekiyor. Burası yatılı okul mu, taşımalı öğrencilerin geldiği bir okul mu? Yatılı okulsa fiziki şartlarımızın geliştirilmesi gerekiyor. Okul dışı sosyal etkinliklerin mutlaka olması gerekiyor. En azından küçük bir tiyatro salonu tarzı bir yerin yapılması gerekiyor. Teknolojik odaların arttırılması gerekiyor. Birinci ve ikinci kademenin kullanabileceği ayrı laboratuvarlar oluşturulması gerekiyor. ... Müfredata gelirsek biraz daha ek kurslar mı olacak çocuklara artık, veli bilgilendirilmesi mi olacak, öncelikle mutlaka müfredatın ne istediğinin öğretmene, idareciye, veliye anlatılması gerekiyor ki idare günü birlik gelişmeleri takip etmek zorunda ve öğretmene bildirmek zorunda. Öğretmen de hizmet için eğitim seminerler sayesinde veya kendi bireysel çabalarıyla kendisini geliştirmek zorunda. Maalesef hizmet içi eğitim seminerleri yok ve yetersiz özellikle de ilçede kalan bir öğretmen için yok denecek kadar az. Bir de pek kitaplarımızı incelemiyoruz en başta. İncelememiz gerekiyor. Ama her şey öğrenci de bitiyor. Öğrencinin hazır olması gerekiyor derse. Öğrenciyi hazırlamak için de diğer şartları hazırlamak gerekiyor mutlaka. Bir üçgen diyelim, öğretmen-okul-veli işbirliği, program bunu şart kılıyor bence." 
YİBO'da görevli sınıf öğretmenlerinin programlara eklenmesini istedikleri önerilere bakıldığında; programların bölgesel farklılıklar dikkate alınarak hazırlanmasını, hazırlanan programın öğretmenlere uzun süreli ve uygulamalı eğitim seminerleriyle tanıtılmasını, her okulun program uygulanmaya başlatılmadan fiziksel şartlar ve teknik donanım açısından programa yönelik hazırlanmasını, programların ülke genelinde öğretmenlerden bilgi alınıp hazırlanmasını önerdikleri görülmüştür. Aslında bu önerilerin programlara eklenecek öneriler olmadığı, bunun yerine programların geliştirilmesi ve uygulamaya konuluş biçimine ilişkin öneriler olduğu dikkat çekmektedir. Öğretmen $\left(\mathrm{YK}_{9}\right)$, programın bölgesel farklılıkların dikkate alınarak hazırlanması gerektiğini belirtmiştir:

"Ben bir kere kesinlikle Türkiye'de eğitim programının uygulanışını en az üçe bölmek isterdim. Bölgelere göre, okulların fiziki imkânlarına göre. Ben beş yıl birleştirilmiş sınıf okuttum. Bir birleştirilmiş sınıfta programı uygulamak gerçekten zor. ... En azından birleştirilmiş sınıflar için ayrı bir program, ilçemiz gibi imkânları kısıtlı, taşra gibi yerler için başka bir program, biraz daha merkezi, imkânları iyi yerler için farklı bir program uygulamakta ben fayda görüyorum. Çünkü ne kadar olsa Ankara merkezdeki eğitimle siz ne kadar çabalasanız da, ögrenciniz ne kadar iyi olsa da buradaki eğitim aynı değil."

Öğretmenlerin ilköğretim programına yönelik yapacakları değişiklik önerileri incelendiğinde; programda yer alan etkinlik sayılarının azaltılması, okuma yazma öğretim yönteminin değişmesi, bitişik eğik yazı yerine dik temel harflerin kullanılması, ölçme değerlendirme sürecinde formlarla ilgili düzenlemeler yapılmasını önerdikleri görülmektedir. Öğretmen $\left(\mathrm{YK}_{6}\right)$, bitişik eğik yazının öğrencilere bir faydası olmadığını şöyle belirtmiştir:

"Ben bitişik eğik yazının öğrencilere hiçbir faydası olmadığını düşünüyorum. Çünkü bizim öğrencilerimiz bu yazıyı bu teknolojide hiçbir yerde kullanmıyor. Bizim görselimiz, kitaplarımız, TV, basınımız, yayınımız normal yazı. Eğik yazıyla öğrenciyi uğraştırmanın hiçbir anlamı yok. Ben uygulama yapmadım çünkü program değişeli hiç birinci sınıf okutmadım. Okutsam şahsen zorlanacağımı düşünüyorum."

Öğretmen $\left(\mathrm{YK}_{8}\right)$, bitişik eğik yazı uygulamasını işlevsel bulmadığını vurgulamıştır:

"Mesela el yazısı her öğrenci için aynı kolaylıkta değil. Ama bunu savunmak için işte bizim Türk milletinin el hareketine uygun gibi şeyler ortaya atıldı. Niye yıllarca biz düz yazı yazmak için uğraştık, getirdi bunu koydu önümüze. Bence serbest bırakılmalı. O kadar da illa el yazsı yazacaksın diye bir şey olmamalı. Zaten eskiden de güzel yazı diye bir ders vardı yazıyorduk. Bence direkt alıştırılması da zorluk. Bayağı bir zorluk oluyor öğrenci açısından. İşlevsel değil bence."

Öğretmen $\left(\mathrm{YK}_{15}\right)$, okuma yazma öğretme yöntemine ilişkin değişiklik yapılabileceğini belirtmiştir:

"Bu okuma yazma şekline bir çözüm bulurum. Yani ses temelli yöntemi, dediğim gibi daha hızlı olabilecek bir şekle getirmeyi önerirdim herhalde. Örneğin ikinci 
sınıfta belki bir hızlı okuma tekniği dersi konulabilir. Onu önerirdim herhalde. Onun dışında çıkarılmasını istediğim herhangi bir şey yok."

Öğretmen $\left(\mathrm{YK}_{7}\right)$, ölçme değerlendirmede sonucun değerlendirilmesi gerektiğini ifade etmiştir:

"Önceki ölçme değerlendirme de bana çok sağlıksız gelmiyordu aslında. Evet, süreç değerlendirilmeli, bu ölçme değerlendirmede süreç değerlendiriliyor, ama sürecin sonunda da ulaştığınız bir şey var. Bu belli. ... Öğretmen zaten süreci değerlendirecektir. $\mathrm{Bu}$ çocuk çalışarak $\mathrm{m}$ yaptı, katılıyor mu? Öğretmen bunun değerlendirmesini yapar zaten. Tutup o forma değil de yani. Ama asıl değerlendirme bence somut olmalı. Çocuk bunu yapıyordur ya da yapmıyordur. Ben geçen yıl öyle bir çizelge oluşturdum, açıç̧ası ölçme değerlendirme formlarını çok fazla kullanmadım. Kullandıysam da işaretledim. O formda mesela toplama işlemini yapıyor evet, doğru telaffuz ediyor evet. Çünkü sene sonunda çocuğun nerden nereye geldiğini, benim verdiğim kazanımların ne kadarını yaptığını görmem lazım. Tamam, belki süreçte çok iyi çocuk. İyi olup olmadığını da ben oradan göreceğim. Ama ben sonuç elde edemiyorum. Bence sonuç önemli. Bunu değiştirirdim."

\section{TARTIŞMA}

YİBO'larda görev yapan sınıf öğretmenlerinin ilköğretim programları hakkındaki görüşlerini belirlemeyi amaçlayan bu araştırmada öğretmenlerin büyük çoğunluğu (12 öğretmen) 2005 ilköğretim programlarını; programın öğrenci merkezli olması ve öğrencinin sürece aktif şekilde katılması, öğrencinin daha kolay öğrenmesini sağlaması, uygulamaların kalıcı bilgi sağlaması, öğrencinin araştırma becerisi kazanması, öğretim sürecini eğlenceli hale getirmesi, kılavuz kitapların işlevsel olması ve teknoloji kullanımını gerekli kılması gibi nedenlerle tercih ettiklerini belirtmişlerdir.

Bunun yanı sıra, sayıca az da olsa bazı öğretmenlerin eski ve yeni programı harmanlayarak uyguladıklarını, içerik boyutu ve okuma yazma öğretim yöntemi açısından 2005 yılı öncesinde uygulanan programı daha etkili bulduklarını, programın eksik ve düzeltilmesi gereken kısımlarının olduğunu vurgulamaları ve bu nedenle programdan kısmen memnun olduklarını belirttikleri görülmektedir. Ancak bu nedenlerin bir kısmının YİBO'lara özgü nedenler olmadığı söylenebilir. Aslında benzer sorunlar diğer ilköğretim kurumlarında gerçekleştirilen uygulamalar için de dile getirilmiştir. Örneğin, sınıf öğretmenlerinin 2005 ilköğretim programının okuma yazma yöntemini uygun bulmadıklarını belirleyen araştırmalara rastlanmaktadır (Çelenk, 2002; Korkmaz, 2006; Baydık ve Kudret, 2012). Benzer şekilde, öğretmenlerin ilköğretim programlarının içerik olarak yetersiz olduğunu ve bölge koşullarıyla örtüşmediğini düşündüklerini ortaya koyan araştırmalar bulunmaktadır (Yapıcı ve Demirdelen, 2007; Yılmaz, 2008; Uygun ve Genç, 2008). Ayrıca, bazı öğretmenlerin özellikle veli katılımını gerekli kılan bu programın, YİBO'larda çeşitli sıkıntılar yarattığını 
ve bu durumun da programı daha az benimsemelerine neden olduğunu belirttikleri görülmektedir. Öğrencilerin yatılı olması ve aileleri ile hafta içi görüşememeleri, ailelerin çocuklarının okul yaşamına ilgisiz kalmaları ya da çocukları ile yeterli iletişim kurma imkânlarının olamaması nedeniyle programın başarısının gölgelendiği dile getirilmektedir.

YİBO'larda görevli sınıf öğretmenlerinin çoğunluğu, 2005 programının etkili ve verimli bir şekilde uygulanabilmesi için ihtiyaç duyulan fiziksel koşulların kurumlarında sağlandığını, öğretmen sayısı ve idari kadro açısından da sıkıntı yaşanmadığını belirtmişlerdir. Bunun yanı sıra, öğretmenlerin bir kısmı, fiziksel donanımın yetersiz olması ve bulundukları çevrenin koşullarından dolayı programın uygulanmasında sıkıntılar yaşadıklarını ifade etmişlerdir. Özellikle yatılı öğrencilerin materyal, araç gereç temini konusunda sıkıntı yaşadıklarını, araştırma yaparken bilgisayara ulaşma konusunda sıkıntı çektiklerini vurgulamışlardır. Okulların sahip olduğu fiziksel olanaklar öğretim programlarının uygulanması açısından önemlidir. Fen ve teknoloji, matematik ve bilgisayar laboratuvarlarının varlığı, bunlara ait araç gereçlerin durumu ve kullanılabilirliği programın hedeflerinin gerçekleşmesinde oldukça önemlidir. Ayrıca öğretim programında öngörülen etkinlikleri gerçekleştirmek için eğitim amaçlı kullanılan teknolojik araçların varlığı programın uygulamada başarılı olmasını önemli ölçüde etkilemektedir (Gömleksiz ve Bulut, 2008).

Öğretmenlerin çoğunluğu, 2005 programının etkili ve verimli bir şekilde uygulanabilmesi için ihtiyaç duyulan sosyal ortamın kurumlarında sağlandığını, öğretmenler arası ve okul yönetimi ile uygulamalara yönelik işbirliği yapılabildiğini belirtmişlerdir. Bununla birlikte bir kısım öğretmen okul yöneticilerinin programa ilişkin bilgi eksikliği nedeniyle işbirliği ile öğretmenler arası ve okul yönetimiyle iletişimde sıkıntı yaşandığını belirtmiștir.

YİBO'ların duyuşsal ortamına ilişkin olarak, üç öğretmen kendisini çalıştığı kuruma ait hissetmediğini ve bu durumun performanslarını olumsuz yönde etkilediğini belirtirken; öğretmenlerinin büyük çoğunluğu, 2005 programının etkili ve verimli bir şekilde uygulanabilmesi için ihtiyaç duyulan akademik desteğin kurumlarında yeterli düzeyde sağlanmadığının altını çizmişlerdir. Can (2005) tarafından yapılan bir araştırmada da ilköğretim programlarının eğitim çalışanlarına yeterince açıklanamaması ve geleneksel bürokratik yöneticilik rollerinden çıkılamaması gibi nedenlerle okul yöneticilerinin öğretim programları hakkında yeterli bilgiye sahip olamadıkları, programla ilgili araç gereçlerin inceleme ve seçimine aktif olarak katılamadıkları ve öğretmenlerin bilgi, deyimlerini birbirleriyle paylaşabilecekleri ortamlar hazırlama yeterliliğine de sahip olmadıkları bulgusuna ulaşılmıştır. Atmaca (2007)'nın yaptığı bir araştırmada, okul müdürleri yeni programlarla ilgili olarak okul içi ve dişı bilgilendirme 
etkinliklerini orta düzeyde gerçekleştirdiklerini söylemişlerdir. Okul müdürleri ayrıca programa yönelik yapılan hizmet içi eğitim etkinliklerini yeterli görmediklerini de belirtmişlerdir. Atmaca (2007)'nın araştırmasındaki yönetici görüşleri bu araştırma bulgularıyla da örtüşmektedir.

YİBO'larda görev yapan sınıf öğretmenlerinin 2005 programının uygulanmasında yaşadıkları güçlüklere ilişkin görüşleri incelendiğinde; çalışma koşullarının öğretmenler arası işbirliğini engellediği, öğrencilerin ailelerinden uzakta sürekli okulda kalması, 24 saat süren nöbet tutma sistemi, okulların kırsal bölgelerde bulunması işbirliği ve iletişimi engelleyen nedenler olarak gösterilmiştir.

Öğretmenler, velilerin ilgisizliği ve programı tanımamaları nedeniyle uygulamada güçlükler yaşamaktadır. Damğa (2008)'nın araştırmasında, öğretmenlerin, öğretim programının uygulanmasında öğrencilerin dersle ilgili sorunlarının çözümü için özellikle YİBO'larda velilerle işbirliği yapılamadığını belirtmişlerdir. Öğretmen görüşleri bu araştırma sonuçları ile de örtüşmektedir. Öğrencilerin yatılı kalması, istenildiğinde velilerle iletişim kurulamaması, velilerin okul içi ve okul dışı etkinliklerde öğrencilere nasıl yardımcı olacaklarını bilmemeleri gibi nedenlerle veli kaynaklı güçlüklerin yaşandığı söylenebilir.

Öğretmenlerin çoğunluğu, programı anlamayla ilgili sıkıntı yaşamadıklarını belirtmişlerdir. $\mathrm{Bu}$ konuda güçlük yaşadığını belirten öğretmenler ise, program değişikliğine ilişkin yeterince bilgilendirilmediklerini vurgulamışlardır. Araştırma bulgularına göre, öğretmenlerin çoğunun programın teorik kısmı ve uygulama süreci konusunda desteklenmeye ihtiyaç duydukları; bir iki hafta gibi kısa sürede yapılan program tanıtım seminerlerinin amacına ulaşmadığı söylenebilir. Yapıc1 ve Demirdelen (2007)'in araştırmalarına göre, öğretmenlerin \%48'i yeni programa uyum sağlamakta güçlük çektiğini; \%43'ü programa ilişkin hizmet içi eğitimi yetersiz bulduklarını belirtmişlerdir. Altun ve Şahin (2009)'in yapmış oldukları araştırma sonucuna göre, öğretmenlerin \%55'i programı az derecede tanıdığını; \%40'1 program hakkında yeterli düzeyde bilgi sahibi olduğunu ifade etmişlerdir.

Öğretmenlerin programı uygulama konusunda yaşadıkları sorunlara yönelik çözüm önerileri incelendiğinde; öğretmenlerin, yöneticilerin ve velilerin program hakkında bilgilendirilmesi, okullarda eğitim ortamlarının düzenlenmesi, hizmet içi eğitimlerin akademisyenler veya uzmanlar tarafindan verilmesi, okulöncesi eğitimle öğrencilere bazı temel becerilerin kazandırılması, YİBO’larda mutlaka öğretmen-öğrenci-veli-rehberlik servisi-okul yönetimi işbirliğinin sağlanması yönünde benzer görüş belirttikleri görülmektedir. YİBO'ların fiziksel ve sosyal olanaklar, araç gereç ve materyal açısından iyileştirilmesi, eğitim ortamlarının yatılı öğrenciler için yapılandırılması gerektiği önemle vurgulanmıştır. Ayrıca 
programda yer alan etkinliklerin sayısının azaltılmasını, okuma yazma öğretim yönteminin değişmesini, bitişik eğik yazı yerine dik temel harflerin kullanılmasını ve ölçme değerlendirme sürecinde kullanılması önerilen formlarla ilgili düzenlemeler yapılmasını önermişlerdir.

Bütün sonuçlar dikkate alındığında; öğretim programlarında yer alan kazanımların ve etkinliklerin gerçekleştirilmesinde yaşanan sıkıntıları (zaman, malzeme vb.) gidermek için çalışmalar yapılmalı, programların içerikleri sürekli olarak gözden geçirilmelidir. Ayrıca kazanım ve etkinlikler kırsal bölgelerdeki okullar da düşünülerek yapılandırılmalıdır. Öğretmenlerin programları etkili ve verimli şekilde uygulamaları konusunda okul yöneticileri tarafından akademik anlamda desteklenmelerini sağlamak amacıyla okul yöneticilerinin de ilköğretim programlarının yaklaşımı, felsefesi ve genel özellikleri konularında belirli aralıklarla seminer ya da çalıştaylara katılımları sağlanmalı, öğretim liderliği rollerini güçlendirici çalışmalara ivedilikle başlanmalıdır. YİBO'lara devam eden öğrencilerin programın gereklerine uygun olarak yapmaları beklenen araştırma ve proje çalışmalarında kullanabilecekleri donanımlı kütüphanelerin ve bilgisayar laboratuvarlarının oluşturulmasına öncelik verilmelidir. Velilere yönelik olarak hem ilköğretim programları hem de ana-baba eğitimi konularında çalışmalar yapılmalı, velilerin YİBO öğretmenleri ile iletişim ve etkileşimini arttıracak projeler geliştirilmelidir. YIBBO'larda öğretim programlarının uygulanmasını etkileyen faktörler öğretmen görüşleri ile birlikte uzman, yönetici, müfettiş, veli ve öğrenci görüşleri de alınarak ve gözlem çalışmaları da yapılarak daha kapsamlı araştırılmalıdır.

\section{KAYNAKLAR}

Altınsoy, M. (2008). Yatılı İlköğretim Bölge Okullarındaki Yatılı ve Gündüzlü Öğrencilerin Kişisel Bakımlarına İlişkin Uygulamaları. Yayımlanmamış yüksek lisans tezi, Gazi Üniversitesi Eğitim Bilimleri Enstitüsü, Ankara.

Altun, T. ve Şahin, M. (2009). Değişen ilköğretim programının sınıf öğretmenleri üzerindeki psikolojik etkilerinin incelenmesi üzerine nitel bir araştırma. Kastamonu Ë̆itim Dergisi, 17(1), 15-32.

Aralpcan, H. (1998). Yatılı İlköğretim Bölge Okulları'nın Sayısal Gelişimi ve Hizmet Sunduğu Çevre. Yayınlanmamış yüksek lisans tezi, Ankara Üniversitesi Eğitim Bilimleri Enstitüsü, Ankara.

Arı, A. (2002). İlköğretim uygulamalarının değerlendirilmesi (Normal, taşımalı ve yatılı ilköğretim okullarının karşılaştııılması). Milli Eğitim Dergisi,153-154.

Atmaca, N. (2007). Yeni Ĕgitim Programlarına İlköğretim Okullarının ve İlköğretim Okulu Müdürlerinin Hazırbulunuşluk Düzeyleri. Yayınlanmamış yüksek lisans tezi, Yıldız Teknik Üniversitesi Sosyal Bilimler Enstitüsü, İstanbul. 
Baydık, B. ve Kudret, Z. (2012). Öğretmenlerin ses temelli cümle yönteminin etkilerine ve öğretim uygulamalarına ilişkin görüşleri. Ankara Üniversitesi Ĕ̈itim Bilimleri Fakültesi Dergisi. 45(1), 1-22.

Can, N. (2005). Bir Öğretim Lideri Olarak Okul Yöneticisinin İlköğretim Programlarının Geliştirilmesindeki Yeterliliğ̈i. Eğitimde Yansımalar: VIII Yeni İlköğretim Programlarını Değerlendirme Sempozyumu Bildiriler Kitabı içinde (77-86). Ankara: Sim Matbaasi.

Çelenk, S. (2002). İlk okuma-yazma öğretiminde karşılaşılan sorunlara ilişkin öğretmen görüşleri. İlköğretim Online, 1(2), 40-47.

Çılğın, Ö. (2007). Yatılı İlköğretim Bölge Okullarında Öğrenim Gören Öğrenciler İle Velilerinin Beden Eğitimi ve Ders Dışı Etkinliklere Yaklaşımları. Yayınlanmamış yüksek lisans tezi, Gazi Üniversitesi Eğitim Bilimleri Enstitüsü, Ankara.

Damğa, S. (2008). YİBO ve İlkögretim Okullarında Yeni İlköğretim Programlarının Uygulanabilirliğinin Öğretmen Görüşlerine Göre Değerlendirilmesi. Yayınlanmamış yüksek lisans tezi, Onsekiz Mart Üniversitesi Sosyal Bilimler Enstitüsü, Çanakkale.

Fullan, M. G. (1991). The New Meaning of Educational Change. Teachers College Press.

Gülbeyaz, O. (2006). Yatılı İlköğretim Bölge Okulları ve Pansiyonlu İlköğretim Okullarında Görev Yapan Yönetici ve Ögrretmenlerin Örgütsel Stres Kaynakları. Yayımlanmamış yüksek lisans tezi, İnönü Üniversitesi Sosyal Bilimler Enstitüsü, Malatya.

Gündüz, H. (2006). Yatılı Illköğretim Bölge Okullarında Görev Yapan Yönetici ve Öğretmenlerin Tükenmişlik Düzeyleri. Yayınlanmamış yüksek lisans tezi, Dicle Üniversitesi Sosyal Bilimler Enstitüsü, Diyarbakır.

Gömleksiz, M. N. ve Bulut, İ. (2008). Yeni ilköğretim programlarının uygulandığ eğitim ortamına ilişkin öğretmen görüşleri. Çağdaş Eğitim Dergisi, 23-29.

Işıkoğlu, Y. E. (2007). Hakkâri İlinde Bulunan Yatılı İlköğretim Bölge Okullarının Olanakları ve Sorunları. Yayımlanmamış yüksek lisans tezi, Ankara Üniversitesi Eğitim Bilimleri Enstitüsü, Ankara.

Karataş, N. (2006). Yatılı İlköğretim Bölge Okullarında Okuyan Öğrencilerin Boş̧ Zamanlarını Değerlendirme Alışkanlıkları. Yayınlanmamış yüksek lisans tezi, Uludağ Üniversitesi Sağllk Bilimleri Enstitüsü, Bursa.

Kılıç, D. (2001). Yatıll İlköğretim Bölge Okulları ile Diğer İlköğretim Okullarının Toplumsal Fonksiyonların Gerçekleştirme Düzeylerinin Karşılaştırılması. Yayınlanmamış doktora tezi, Atatürk Üniversitesi Sosyal Bilimler Enstitüsü, Erzurum.

Kin, J. \& Chan, S. (2010). Teachers' responses to curriculum policy implementation: colonial constraints for curriculum reform. Educational Research Policy Practice, 9, 93-106. 
Korkmaz, İ. (2006). Yeni ilköğretim birinci sınıf programının öğretmenler tarafından değerlendirilmesi. Selçuk Üniversitesi Sosyal Bilimler Enstitüsü Dergisi, 419-431.

MEB. (2002). Temel Eğitim Projesi, İlköğretim Okullarının Sosyal Etkilerinin Değerlendirilmesi. Milli Eğitim Bakanlığı Projeler Koordinasyon Merkezi Başkanlığı, Ankara.

MEB. (2003). Yatılı İlköğretim Bölge Okulları ve Pansiyonlu İlköğretim Okulları Yönetici Kılavuzu Kitabı. İstanbul: Milli Eğitim Basımevi.

MEB. (2007). Yatılı İlköğretim Bölge Okullarının Yönetimi.[Online]:http://tedp.meb.gov.tr adresinden 06 Mart 2009'da indirilmiştir.

MEB. (2008). Yatılı İlköğretim Bölge Okulları Yönetici Kılavuzu Kitabı. Ankara: Devlet Kitapları Müdürlüğü Basımevi.

MEB. (2010). Milli Eğitim İstatistikleri, Örgün Eğitim. Millî Eğitim Bakanlı̆̆ı Strateji Geliş̧irme Başkanlığı, Ankara.

Miles, M. B. \& Huberman, A. M. (1994). Qualitative Data Analysis. Thousand Oaks, CA: Sage.

Özgündüz, G. (2006). Yatıll İlköğretim Bölge Okullarındaki Öğrenci Velilerinin Ders Dışı Etkinliklere Yaklaşımları. Yayınlanmamış yüksek lisans tezi, Gazi Üniversitesi Eğitim Bilimleri Enstitüsü, Ankara.

Özkaya, H. (2006). Yatılı İlköğretim Bölge Okulu ve İlkögretim Okullarında Görev Yapan Ögrretmenlerin Tükenmişlik Düzeylerinin Öğretmen Görüşleri Açısından Karşılaștırılması. Yayınlanmamıș yüksek lisans tezi, Onsekiz Mart Üniversitesi Sosyal Bilimler Enstitüsü, Çanakkale.

Tavşancıl, E. ve Aslan, A. E. (2001). İçerik Analizi ve Uygulama Örnekleri. (1. Basım). İstanbul: Yeni Çizgi Yayın Dağıtım.

Ulusoy, Y. (2006). Yatılı Okullar. Yayınlanmamış yüksek lisans tezi, Ankara Üniversitesi Eğitim Bilimleri Enstitüsü, Ankara.

Uygun, S. ve Genç, S. Z. (2008). Yeni İlköğretim Programlarının Kuramsal Temelleri Açısından Uygulanabilirliğinin Öğretmen Görüşlerine Göre Değerlendirilmesi. VII. Ulusal Sınıf Öğretmenliği Eğitimi Sempozyumu, Bildiriler, Çanakkale: On Sekiz Mart Üniversitesi.

Yapıcı, M. ve Demirdelen, C. (2007). İlköğretim 4. Sinlf Sosyal Bilgiler Dersine Illişkin Öğretmen Görüşleri. AKU Eğitim Fakültesi. [Online]:http://ilkogretimonline.org.tr adresinden 07.03.2009 tarihinde indirilmiştir.

Yılmaz, B. C. (2008). Yenilenen Fen ve Teknoloji Müfredatında Fen ve Teknoloji Öğretmen Yeterliklerinin Nitel Olarak Belirlendiği Bir Çalışma. Yayınlanmamış yüksek lisans tezi, Karadeniz Teknik Üniversitesi Sosyal Bilimler Enstitüsü, Trabzon. 